\title{
Environmental Radioactivity Comparison Study for the Glaze-Clay Surface of Ceramic Tiles by Tracks Technique
}

\author{
A. F. Maged ${ }^{\#}$ and L. M. Nada \\ Solid State and Electron Accelerator Dept., National Centre \\ for Radiation Research and Technology (NCRRT), P. O. Box; \\ 29 Nasr city, Cairo, Egypt. ${ }^{\#}$ Magedali2000@eaea.org.eg.
}

RACKS DENSITY, radon concentration, radon exhalation
rates and radium concentration were measured from
ceramic tiles for both of glaze and clay by using the track
technique, containing CR-39, to estimate the radiation exposure
in the vicinity of ceramic tile. For ceramic tiles of wall, the
average of tracks density, the radon concentration, radon
exhalation rates and radium concentration were found in the
range $230-356$ tracks.cm ${ }^{-2}, 389-600 \mathrm{~Bq} \cdot \mathrm{m}^{-3}, 21-31 \mathrm{mBq} \cdot \mathrm{m}^{-2} \cdot \mathrm{h}^{-1}$,
$16-25 \mathrm{~Bq} \cdot \mathrm{kg}^{-1}$, respectively. While for ceramic tiles of floor,
the average of tracks density, the radon concentration, radon
exhalation rates and radium concentration were found in the
range $274-509$ tracks.cm ${ }^{-2}, 463-860 \mathrm{~Bq} \cdot \mathrm{m}^{-3}, 25-46 \mathrm{mBq} \cdot \mathrm{m}^{-2} \cdot \mathrm{h}^{-1}$,
$19-46 \mathrm{~Bq} \cdot \mathrm{kg}^{-1}$, respectively. The average level of radon
concentrations caused by these ceramic tiles for Egyptian
companies covering both of wall, floor, glaze and clay giving
an annual exposure dose $22 \pm 2 \mathrm{mSv} \cdot \mathrm{y}^{-1}$ which is higher than
internationally recommended range. Keywords: Track density, CR-39, ceramic tiles, annual effective dose, radon exhalation rate.

Materials obtained from the earth's crust, such as ceramic tiles, may contain traces of ${ }^{238} \mathrm{U}$ and ${ }^{226} \mathrm{Ra}$. These radionuclides decay to radon $\left({ }^{222} \mathrm{Rn}\right)$, which is a radioactive gas with a half-life of 3.82 days. For over a century and a half, soils containing naturally occurring radioactive materials (NORM) have been used in manufacturing glass and ceramic products, as base material (Bruzzi et al., 1993). Recognition of the hazards inherent in such applications led to regulations governing incorporation of byproduct radioactive materials (EC 1999). Raw zirconium sand is one of the substances, NORM which is widely used in the ceramic industry (Verita et al., 2009 and Luisa et al., 2008).

Prolonged exposure to radon may increase the risk of lung cancer (ICRP, 1979, ICRP, 2007, Maged et al., 2000, Popovic et al., 1996, Todorović et al., 
1999 and Saad, 2008) because it delivers $55 \%$ of the total dose to the cells of the respiratory system UNSCEAR (2006). In some, but not all, studies of groups of people either occupationally exposed to, or resident in areas of, high natural radiation, including elevated levels of radon and its decay products, an increased incidence of chromosomal aberrations has been observed. Radon and its decay products did not induce chromosomal aberrations in vivo in rabbits in one laboratory experiment but did induce chromosomal aberrations in human cells in vitro and sex-linked recessive lethal mutations in Drosophila (WHO, 1988).

There were numerous studies confirming indoor radon as a cause of over 20,000 lethal lung cancer cases in EU every year, making about $9 \%$ of all lethal lung cancer cases per year in EU and about $2 \%$ of lethal cancer cases per year in EU in general. The majority of European countries, as well as Canada and USA, proclaimed intervention levels for exposures from radon in closed space and concentrations of radionuclides in building materials. These issues were also regulated by numerous publications and recommendations by international organizations: International Commission for Radiation Protection (ICRP), Radon Indoor Concentrations and Activity of Radionuclides in Building Materials in Serbia, (WHO, 2009), United Nation Commission for Atomic Radiation Research, (UNCEAR, 1989), etc. According to these recommendations the general population should not be exposed to more than $0.7 \mathrm{mSv}$ of radiation from building materials, therefore the total gamma radiation index for radionuclides ${ }^{40} \mathrm{~K},{ }^{226} \mathrm{Ra}$ and ${ }^{232} \mathrm{Th}$ should not be higher than 1 .

Due to the long half-life of radon gas, it can reach from the earth's crust or from the walls and floors of buildings into both outdoor and indoor air. In the case of indoor air, the risk of exposure to radon is higher, especially for buildings with poor ventilation systems, which may lead to a higher indoor concentration of radon. In the last 20 years, more attention has been paid to the measurement of radon exhalation from building materials in many countries worldwide, including Great Britain, Finland, (Mustonen, 1984), Taiwan, (Ching-Jiang et al., 1993), Greece, (Savidou et al., 1996), Turkey, (Turhan, 2008) and Egypt, (Maged et al., 2005). In light of this information, and due to the lack of radon exhalation studies from construction materials in Egypt, it is important to begin this preliminary study to measure the track density, the radon

Egypt. J. Rad. Sci. Applic., Vol. 24, No. 1 (2011) 
concentration, the radon exhalation rates, radium concentration and annual effective doses in situations where construction materials are a significant source of radon in houses. This particular study will be carried out in the National Centre for Radiation Research and Technology to help in development database for all building materials.

\section{Materials and Methods}

\section{CR-39 detector}

The CR-39 plastic solid-state nuclear track detectors, SSNTDs are a $\mathrm{C}_{12} \mathrm{H}_{18} \mathrm{O}_{7}$ polymer with density $1.3 \mathrm{~g} . \mathrm{cm}^{-3}$. In this work we used CR-39 produced by Page Mouldings (England). A study of tracks density from wallfloor ceramic tiles for both of glaze and clay surface was performed. Measurement of the time-integrated radon exhalation rate was carried out by placing an inverted hollow holder on the ceramic tiles surface for wall and floor. The contact between the hollow holder and those sampled ceramic tiles was covered with filter paper to prevent any alpha particles enter the hollow holder and then sealed with silicone sealant as shown in Fig. 1.

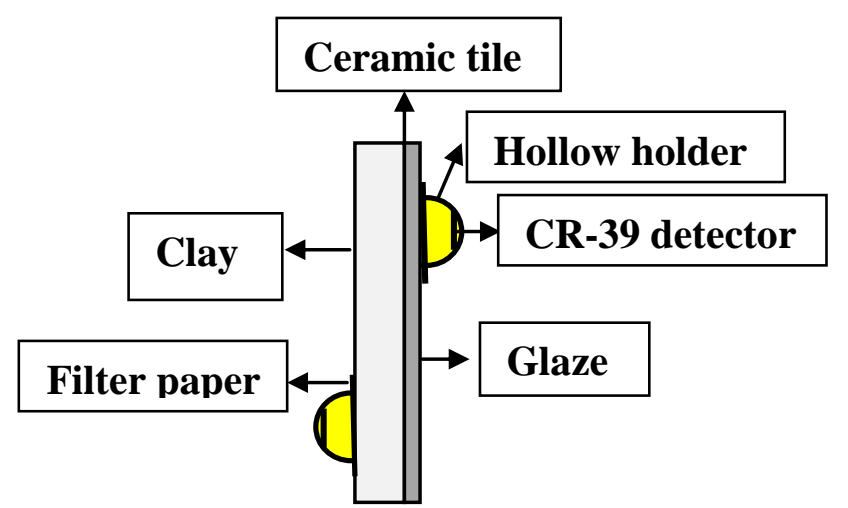

Fig. 1. The setup diagram for measuring radon exhalation rate of ceramic tiles.

The detection system involves the use of SSNTDs of type CR-39, which were cut into small pieces, $1.5 \mathrm{~cm} \times 1.5 \mathrm{~cm}$. Each CR-39 detector was fixed onto the top center of the inverted hollow holder by means of adhesive tag. Once equipped with CR-39 detectors, the hollow holder were properly labeled and mounted for about two weeks in equilibrium. Three detectors were used for each sample. During this exposure time, the tracks of alpha particles from the 
decay of radon and its daughters that had entered the air volume of the hollow holder were registered in the CR-39 plastic detector. The CR-39 plastic detector were removed from the hollow holder and etched chemically in a $6 \mathrm{M} \mathrm{NaOH}$ solution at $70{ }^{\circ} \mathrm{C}$ for $18 \mathrm{~h}$ to display and enlarge the latent alpha tracks due to radon decay. The etched tracks on the detectors were counted manually, using an optical microscope with objective lens $4 \times$ magnification. The average area of one hundred fields of view was calculated by using image analyses system and the track density was calculated in terms of tracks per $\mathrm{cm}^{-2}$. The background track density was determined by processing a virgin detector under the same etching conditions.

The background was subtracted from the measured track density. In order to obtain realistic statistics of the tracks, 100 fields of view were scanned continually to cover the detector surface. The calibration factor obtained from an earlier calibration experiment for the CR-39 track detector (Maged et al., 1993) was used to compute the radon activity from the track density.

\section{Results and Discussion}

The results showed that the ceramic tiles of floor yielded the highest average tracks density values, while the ceramic tiles of wall produced the lowest values. However, the average values of radon concentrations from the floor tiles are higher than the wall tiles and this may be due to the thickness of floor tiles is higher. For the glaze of wall ceramic tiles, the tracks density, the radon concentration, the exhalation rate and radium concentration according to Culot et al. (976) were found $230 \pm 36$ tracks.cm ${ }^{-3}, 289 \pm 61 \mathrm{~Bq} \cdot \mathrm{m}^{-3}, 21 \pm 3 \mathrm{mBq} \cdot \mathrm{m}^{-2} \cdot \mathrm{h}^{-1}$, and $16 \pm 3 \mathrm{~Bq} \cdot \mathrm{kg}^{-1}$, respectively. While for clay of wall ceramic tiles, the tracks density, the radon concentration, the exhalation rate and radium concentration were found $356 \pm 31$ tracks.cm ${ }^{-3}, 600 \pm 53$ Bq. $\mathrm{m}^{-3}, 32 \pm 3 \mathrm{mBq} \cdot \mathrm{m}^{-2} \cdot \mathrm{h}^{-1}$, and $25 \pm 2 \mathrm{~Bq} \cdot \mathrm{kg}^{-1}$, respectively as shown in Table 1 .

The glaze of floor ceramic tiles, the tracks density, the radon concentration, the exhalation rate and radium concentration were found $274 \pm 35$ tracks.cm ${ }^{-3}, 463 \pm 58 \mathrm{~Bq} \cdot \mathrm{m}^{-3}, 25 \pm 3 \mathrm{mBq} \cdot \mathrm{m}^{-2} \cdot \mathrm{h}^{-1}$, and $19 \pm 2 \mathrm{~Bq} \cdot \mathrm{kg}^{-1}$, respectively. While for the clay of floor ceramic tiles, the tracks density, the radon concentration, the exhalation rate and radium concentration were found 509 \pm 41

Egypt. J. Rad. Sci. Applic., Vol. 24, No. 1 (2011) 
tracks.cm ${ }^{-3}, 860 \pm 69$ Bq. $\mathrm{m}^{-3}, 46 \pm 4 \mathrm{mBq} \cdot \mathrm{m}^{-2} \cdot \mathrm{h}^{-1}$, and $36 \pm 3 \mathrm{~Bq} \cdot \mathrm{kg}^{-1}$, respectively as shown in Table 2.

TABLE 1. Represents the ceramic tiles wall parameters as the track density ( $\rho)$, the radon concentration $(C)$, the exhalation rate $(E)$ and the radium concentration (Ra) for glaze and clay surface.

\begin{tabular}{|c|c|c|c|c|c|c|c|c|}
\hline \multicolumn{9}{|c|}{ Ceramic tile wall } \\
\hline \multicolumn{4}{|c|}{ Glaze } & \multicolumn{5}{|c|}{ Clay } \\
\hline $\begin{array}{l}\text { Code } \\
\text { No. }\end{array}$ & $\begin{array}{c}\rho \\
\text { tracks. } \\
\text { cm }^{-2}\end{array}$ & $\begin{array}{c}\mathrm{C} \\
\text { Bq. } \\
\mathbf{m}^{-3}\end{array}$ & $\begin{array}{c}\mathbf{E} \\
\mathbf{m B q} \\
\mathbf{m}^{-2} \cdot \mathbf{h}^{-1}\end{array}$ & $\underset{\text { Bq.kg }}{\mathbf{R a}}$ & $\begin{array}{c}\rho \\
\text { tracks. } \\
\text { cm }^{-2}\end{array}$ & $\begin{array}{c}\mathrm{C} \\
\mathbf{B q} \cdot \mathrm{m}^{-3}\end{array}$ & $\begin{array}{c}\mathbf{E} \\
\mathbf{m B q} \\
\mathbf{m}^{-2} \cdot \mathbf{h}^{-1}\end{array}$ & $\underset{\text { Bq. }}{\text { Ra }} \mathrm{kg}^{-1}$ \\
\hline 1 & 220 & 372 & 20 & 15 & 318 & 537 & 29 & 23 \\
\hline 2 & 290 & 490 & 26 & 22 & 380 & 642 & 34 & 26 \\
\hline 3 & 260 & 439 & 24 & 19 & 390 & 659 & 35 & 27 \\
\hline 4 & 240 & 406 & 22 & 17 & 350 & 591 & 32 & 25 \\
\hline 5 & 175 & 296 & 16 & 12 & 370 & 625 & 33 & 26 \\
\hline 6 & 280 & 473 & 25 & 19 & 360 & 608 & 32 & 25 \\
\hline 7 & 220 & 372 & 20 & 16 & 365 & 617 & 34 & 26 \\
\hline 8 & 250 & 422 & 23 & 18 & 370 & 625 & 33 & 25 \\
\hline 9 & 230 & 389 & 21 & 16 & 370 & 623 & 32 & 25 \\
\hline 10 & 255 & 431 & 23 & 18 & 400 & 676 & 36 & 28 \\
\hline 11 & 190 & 321 & 17 & 13 & 320 & 541 & 29 & 22 \\
\hline 12 & 190 & 321 & 17 & 14 & 290 & 490 & 26 & 20 \\
\hline 13 & 195 & 329 & 18 & 14 & 340 & 574 & 31 & 24 \\
\hline Mean & 230 & 389 & 21 & 16 & 356 & 600 & 32 & 25 \\
\hline SD & 36 & 61 & 3 & 3 & 31 & 53 & 3 & 2 \\
\hline Max & 290 & 490 & 26 & 22 & 400 & 676 & 36 & 28 \\
\hline Min & 175 & 296 & 16 & 12 & 350 & 591 & 32 & 25 \\
\hline
\end{tabular}

The average value for all ceramic tiles for the different companies were found for the tracks density, the radon concentration, the exhalation rate and equivalent dose according to (UNSCEAR, 2000) were found $390 \pm 46$ tracks.cm ${ }^{3}, 661 \pm 68 \mathrm{~Bq} \cdot \mathrm{m}^{-3}, 39 \pm 5 \mathrm{mBq} \cdot \mathrm{m}^{-2} \cdot \mathrm{h}^{-1}$, and , $22 \pm 2 \mathrm{mSv} \cdot \mathrm{y}^{-1}$, respectively as shown in Table 3.

The radium concentration in Egyptian ceramic is still less than others (EC, 1999, Verita et al., 2009 and Luisa et al., 2008). The alpha tracks density ( $\rho)$ due to alpha particles which emitted from radon comes out from ceramic tiles appeared in one field (from 100 fields) in CR-39 detector by using objective magnification 20X for Egyptian ceramic companies is shown in Fig. 2.

Egypt. J. Rad. Sci. Applic., Vol. 24, No. 1 (2011) 
TABLE 2. Represents the ceramic tile floor parameters as the track density ( $\rho)$, the radon concentration $(C)$, the exhalation rate $(E)$ and the radium concentration (Ra) for glaze and clay surface.

\begin{tabular}{|c|c|c|c|c|c|c|c|c|}
\hline \multicolumn{9}{|c|}{ Ceramic tile wall } \\
\hline \multicolumn{4}{|c|}{ Glaze } & \multicolumn{5}{|c|}{ Clay } \\
\hline $\begin{array}{l}\text { Code } \\
\text { No. }\end{array}$ & $\begin{array}{c}\rho \\
\text { tracks.cm }\end{array}$ & $\begin{array}{c}\text { C } \\
\text { Bq.m }{ }^{-3}\end{array}$ & $\begin{array}{l}\text { E mBq. } \\
\mathbf{m}^{-2} \cdot h^{-1}\end{array}$ & $\begin{array}{c}\mathbf{R a} \\
\mathrm{Bq} \cdot \mathrm{kg}^{-1}\end{array}$ & $\begin{array}{c}\rho \\
\text { tracks.cm }^{-2} \\
\end{array}$ & $\begin{array}{c}\text { C } \\
\text { Bq. } \mathrm{m}^{-3}\end{array}$ & $\begin{array}{l}\text { EmBq. } \\
\mathbf{m}^{-2} \cdot \mathbf{h}^{-1}\end{array}$ & $\begin{array}{c}\text { Ra } \\
\text { Bq.kg-1 }\end{array}$ \\
\hline 1 & 260 & $\varepsilon r q$ & ro & 19 & $\Sigma V \cdot$ & V9 & $\varepsilon r$ & $r 3$ \\
\hline$r$ & rT. & $0 \leqslant 1$ & $r \cdot$ & Tr & $\leqslant 0$. & V.. & §1 & $r 2$ \\
\hline$r$ & r70 & $\varepsilon \leqslant \wedge$ & $T \varepsilon$ & 19 & Or. & $\wedge \vee q$ & $\varepsilon V$ & $r 7$ \\
\hline$\varepsilon$ & TO. & $\varepsilon Y \leqslant$ & $T \varepsilon$ & 11 & $\leqslant 7$. & $V V V$ & $\varepsilon r$ & $r 3$ \\
\hline 0 & Tr. & r^9 & YI & 17 & $0 \ldots$ & $\Lambda \leq 0$ & $\sum 7$ & ru \\
\hline 7 & ए. & OY & TA & TY & 01. & ATY & $\leqslant 7$ & r6 \\
\hline $\mathrm{V}$ & ro. & EYY & Tr & 18 & $0 \leqslant 0$ & 941 & 0. & r9 \\
\hline$\Lambda$ & rA. & $\varepsilon V \mu$ & To & 19 & $0 \leqslant$. & 911 & $\varepsilon 9$ & r8 \\
\hline 9 & קr. & 001 & W & Tr & Or. & AVq & $\Sigma V$ & T \\
\hline 1. & $r \leq 0$ & $\varepsilon 1 \leqslant$ & TY & IV & $0 \wedge$. & $9 \wedge$. & or & $\S 1$ \\
\hline Mean & TVE & \&74 & To & 19 & 0.9 & $\Lambda 7$. & $\sum 7$ & r6 \\
\hline SD & $r 5$ & 01 & $r$ & $r$ & ミ1 & 79 & 4 & 3 \\
\hline Max & rr. & 001 & $r$ & Tr & $0 \wedge$. & 91. & or & \&1 \\
\hline Min & rr. & r^q & rI & 17 & $\leqslant 0$. & 17. & \&1 & $r 2$ \\
\hline
\end{tabular}

TABLE 3. The average value of all ceramic tiles for all the companies.

\begin{tabular}{|c|c|c|c|c|c|}
\hline Code & $\begin{array}{l}\text { Company trade } \\
\text { mark }\end{array}$ & $\begin{array}{l}\text { Track density } \\
(\text { tracks.cm²) }\end{array}$ & $\begin{array}{c}\text { Radon conce } \\
\text { ntration } \\
\left(\text { Bq.m }{ }^{-3}\right)\end{array}$ & $\begin{array}{c}\text { Exhalation rate } \\
\left(\mathbf{m B q} \cdot \mathbf{m}^{-2} \cdot \mathbf{h}^{-1}\right)\end{array}$ & $\begin{array}{c}\text { Equivalent } \\
\text { dose } \\
\left(\mathrm{mSv}^{-1} \mathbf{y}^{-1}\right)\end{array}$ \\
\hline 1 & Cleopatra & 377 & 637 & 37 & 21 \\
\hline 2 & Aracemco & 431 & 728 & 43 & 24 \\
\hline 3 & Lecico & 430 & 727 & 43 & 24 \\
\hline 4 & Venecia & 387 & 654 & 37 & 21 \\
\hline 5 & Pharaoho & 381 & 644 & 43 & 21 \\
\hline 6 & El-Gawhara & 430 & 728 & 42 & 24 \\
\hline 7 & Misr & 416 & 703 & 41 & 23 \\
\hline 8 & Alfa & 434 & 733 & 43 & 24 \\
\hline 9 & Alamir & 444 & 751 & 44 & 25 \\
\hline 10 & Royal & 394 & 673 & 38 & 22 \\
\hline 11 & ND & 331 & 559 & 33 & 18 \\
\hline 12 & ND & 288 & 486 & 28 & 16 \\
\hline 13 & ND & 337 & 569 & 33 & 18 \\
\hline Mean & & 390 & 661 & 39 & 22 \\
\hline Max & & 444 & 751 & 44 & 25 \\
\hline Min & & 288 & 486 & 28 & 16 \\
\hline SD & & 46 & 68 & 5 & 2 \\
\hline
\end{tabular}

${ }^{\text {a) }}$ E.E.C $=$ Equilibrium Equivalent concentration.

Egypt. J. Rad. Sci. Applic., Vol. 24, No. 1 (2011) 


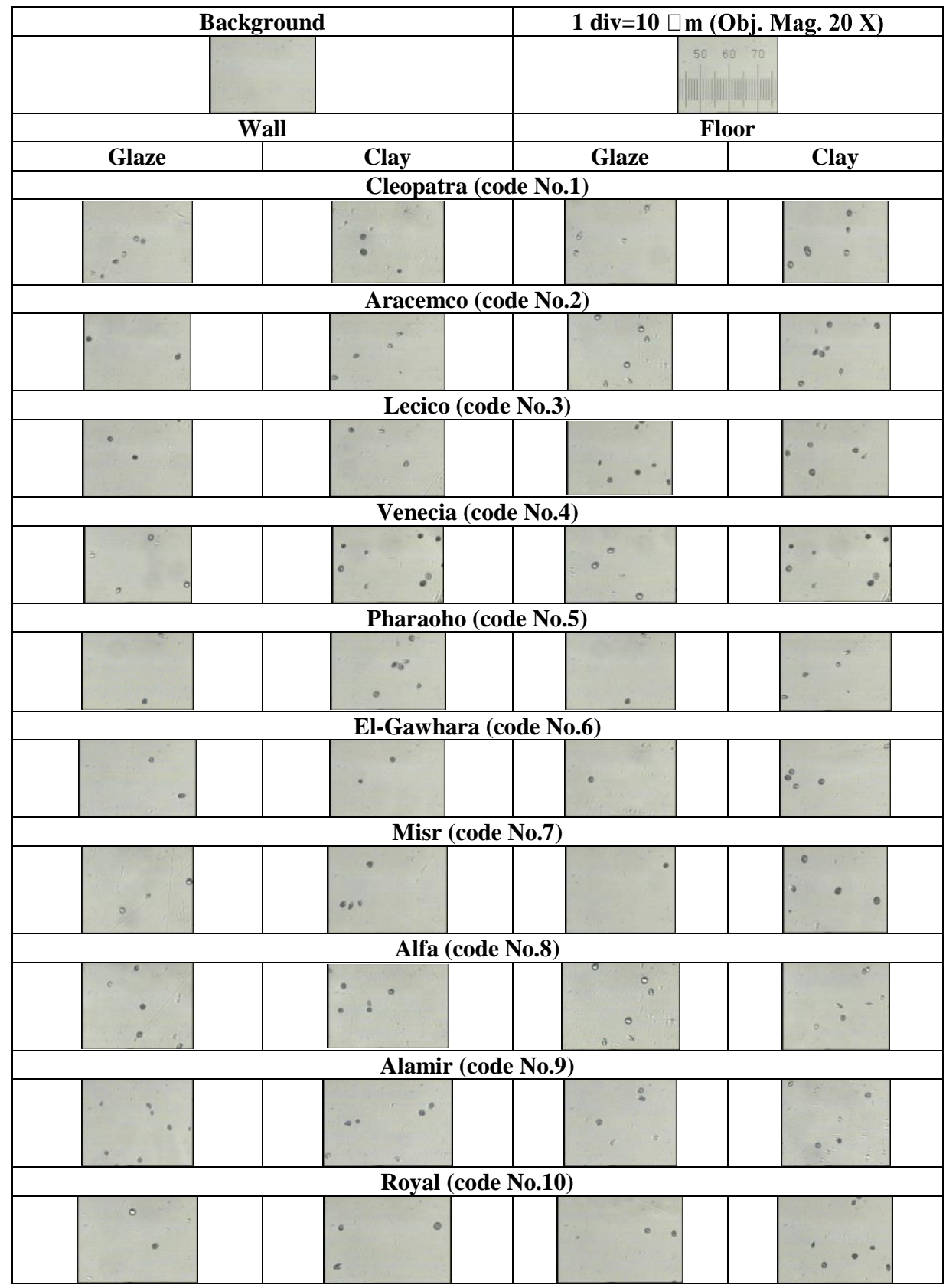

Fig. 2. Photographs showing the alpha tracks density $(\rho)$ appeared in one field (from 100 fields) in CR-39 detector by using objective magnification 20X for Egyptian ceramic companies.

Egypt. J. Rad. Sci. Applic., Vol. 24, No. 1 (2011) 


\section{Conclusion}

The range of ceramic tiles for the tracks density, the radon concentration, the exhalation rate and radium concentration were found 175-589 tracks.cm ${ }^{-3}$, 296-980 Bq. $\mathrm{m}^{-3}, 16-53 \mathrm{mBq} \cdot \mathrm{m}^{-2} \cdot \mathrm{h}^{-1}$, and 12-41 Bq. $\mathrm{kg}^{-1}$, respectively. All the measuring parameters for the floor ceramic tiles were higher than the wall ceramic tiles. The average level of radon concentrations caused by these ceramic tiles for Egyptian companies covering both of wall, floor, glaze and clay giving an annual exposure dose $22 \pm 2 \mathrm{mSv}^{-1}{ }^{-1}$ which is higher than internationally recommended range.

\section{References}

Bruzzi, L., Mele, R., Cazzoli, S. and Tenaglia, A. (1993) Certification of natural radioactivity in ceramic building materials: methods and problems still open. Regional Meeting: Nuclear Energy in Central Europe Present and Perspectives, Portorož, Slovenia, 13-16 June 1993.

Ching-Jiang, C., Pao-Shan, W. and Fieh-Chi, C. (1993) Radon Exhalation Rate fromVarious Building Materials. Health Physics, 64, 613.

Culot M. V. J., Olson, H. G. and Schiager, K. J. (1976) Effective diffusion coefficient if radon in concrete, Theory and Methods for Field Measurements, Health Phys., 30, 263.

EC (European Commission) (1999) Radiological Protection Principles Concerning the Natural Radioactivity of Building Materials, Radiation Protection Report RP112, Directorate-General Environment Nuclear Safety and Civil Protection, Luxembourg.

ICRP (International Commission on Radiological Protection) (1979) Lung Cancer Risks from Indoor Exposure to Radon Daughters. Report 50, Vol. 17, No. 1.

ICRP (International Commission on Radiological Protection) (2007) Scope of Radiological Protection Control Measures, Publication 104, Annals of the ICRP Vol. 37, Elsevier.

Luisa, B., Isidoro, Z. Josefina, O. and Vicente, S. (2008) Occupational exposure to natura radioactivity in a zircon sand milling plant. J. Environ. Radioact., 99, 1525 .

Maged, A. F., Mokhtar, G. M., El-Tobgui, M. M., Gabbr A. A., Attia N. I. and Abu shady, M. M. (2000) Domestic radon concentration and childhood cancer study in cairo (Egypt) Environ. Carcino. Ecotox. Revs., C18, 153.

Maged, A. F. and Ashraf, F. A. (2005) Radon exhalation rate of some building materials used in Egypt. J. Environ. Geochem. Health, 27, 485.

Maged, A. F., Tsuruta, T. and Durrani, S. A. (1993) Experimental and Theoretical Considerations on the Calibration Factor K between $\alpha$-Activity Concentration

Egypt. J. Rad. Sci. Applic., Vol. 24, No. 1 (2011) 
and Track Density for Application in Radon Dosimetry. J. Radioanalyt. Nucl. Chem., 170, 423.

Mustonen, R. (1984) Natural Radioactivity in and Radon Exhalation from Building Materials. Health Phys., 46, 1195.

Popovic, D., Djuric, G. and Todorovic, D. (1996) Radionuclides in building and radon indoor concentrations. Radiat. Protect. Dosimetry, 63, 223.

Saad, A. F. (2008) Radium activity and radon exhalation rates from phosphate ores using CR-39 on-line with an electronic radon gas analyzer 'Alpha Gurad. Radiat. Measurem., 43, S463.

Savidou, A., Rapits, C. and Kritidis, P (1996) Study of natural radionuclides and radon emanation in bricks used in the attica region, Greece. J. Environ. Radioact., 31, 21.

Todorovic, D., Popovic, D. and Djuric, G. (1999) Radionuclides in raw building materials. Izgradnja, 53, 330 .

Turhan, S. (2008) Assessment of the natural radioactivity and radiological hazards in turkish cement and its raw materials. J. Environ. Radioact., 99, 404.

UNSCEAR (United Nation Commission for Atomic Radiation Research) (2006) Sources-to-effects assessment for radon in homes and workplaces. Vol. II, UNSCEAR 2006 Report.

UNSCEAR (United Nations Scientific Committee on the Effects of Atomic Radiation) (2000) Sources, effects and risks of ionizing radiation, Report to the general assembly with annex B: Exposures from Natural Sources of Radiation. United Nations, New York.

UNSCEAR (United Nations Scientific Committee on the Effects of Atomic Radiation) (1989) Sources, Effects and Risk of Ionizing Radiation., Report to the General Assembly, United Nations, New York.

Verita, S., Righi, S., Guerra, R. and Jeyapandian, M. (2009) Radon exhalation rats from zircon sands and ceramic tiles in Italy. Radioprot., 44, 445.

WHO (World Health Organization) (1988) International Agency for Research on Cancer "IARC" Monographs on the Evaluation of Carcinogenic Risks to Humans. Vol. 43, Man-made Mineral Fibers and Radon, Lyon, France.

WHO (World Health Organization) (2009) WHO handbook on Indoor Radon: A Public Health Perspective. Geneva: WHO, ISBN 978924154767 3, WHO Library Cataloguing-in -Publication Data.

(Received: 02/06/2011;

accepted: 13/07/2011)

Egypt. J. Rad. Sci. Applic., Vol. 24, No. 1 (2011) 


$$
\begin{aligned}
& \text { دراسه مقارنه للنشاط الأشعاعى البيئي لكل من السطح الخزفى الإنى }
\end{aligned}
$$

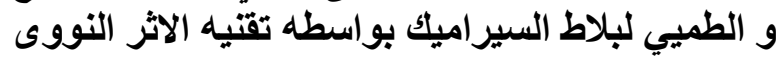

$$
\begin{aligned}
& \text { ماجد علي فهمي و ندا لطفي عبد الرحيم }
\end{aligned}
$$

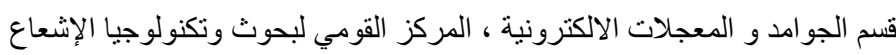

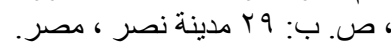

لقد تم دراسه كل من الاثر النووى و تركيز الرادون و معدل

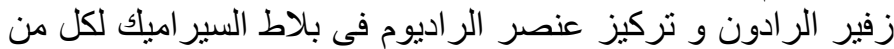

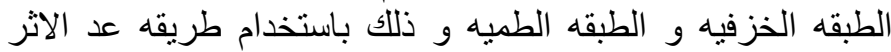

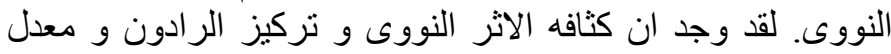

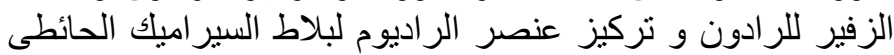

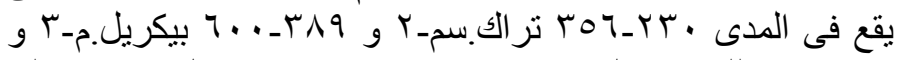

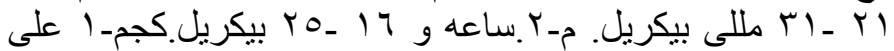

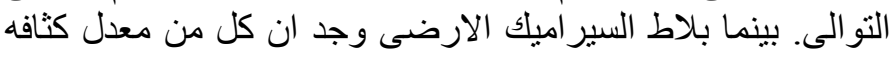

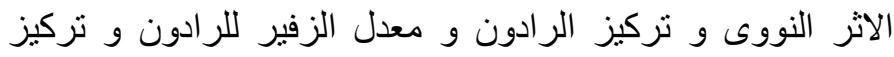

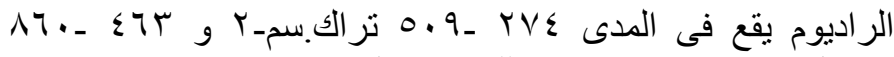

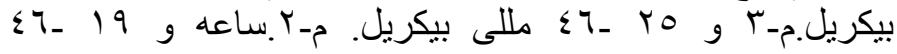

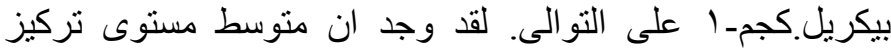

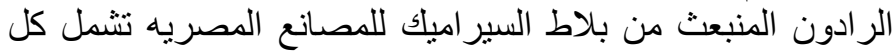

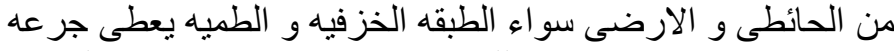

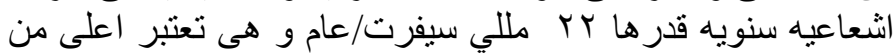

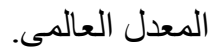

Egypt. J. Rad. Sci. Applic., Vol. 24, No. 1 (2011) 